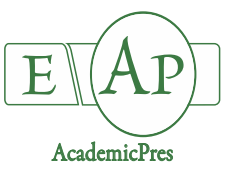

Bintas PA et al. (2020)

Notulae Botanicae Horti Agrobotanici Cluj-Napoca 48(2):978-988

DOI: $10.15835 /$ nbha 48211911

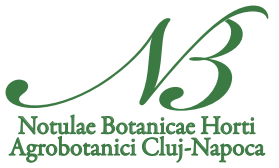

\title{
Investigation of the effects of some bacterial isolates and fertilizer applications on nutrient contents of hyacinth
}

\author{
Pinar A. BINTAŞ ${ }^{1}$, Arzu ÇIĞ ${ }^{1 *}$, Nalan TÜRKOĞLU ${ }^{2}$ \\ ${ }^{1}$ Siirt University, Faculty of Agriculture, Department of Horticulture, Kezer, Siirt, \\ Turkey; pinarbinarc@gmail.com; arzucig@yahoo.com ("correspondingauthor); \\ ${ }^{2}$ Van Yüzüncü Yul University, Faculty of Agriculture, Department of Horticulture, Van, \\ Turkey;nalanturkoglu65@gmail.com
}

\begin{abstract}
This study was conducted to determine the effect of NPK fertilization and some bacterial species on the macro and micro nutrient element contents of Hyacinthus orientalis cv. 'Delft Blue' leaves and bulbs. In the study carried out under laboratory conditions, according to randomized plot experiment design, full and 50\% dose of 20:20:20 NPK commercial fertilizer was applied to hyacinth bulbs as inorganic fertilizer. Nitrogenfixing bacteria: Cellulomonas turbata(TV54A), phosphate solibilizing bacteria: Bacillus-GC Group (TV119E), nitrogen-fixing and phosphate solibilizing bacteria: Kluyvera cryocrescens (TV113C)were used as biological fertilizers. In this study, the highest mean values of nutrients were obtained as nitrogen (N) 3.866\%; phosphorus (P) $334.790 \mathrm{mgkg}^{-1}$; potassium (K) 4.534\%; iron (Fe) $152.453 \mathrm{mgkg}^{-1}$; manganese $(\mathrm{Mn}) 26.739$ $\mathrm{mgkg}^{-1}$; zinc $(\mathrm{Zn}) 46.517 \mathrm{mgkg}^{-1}$ and copper $(\mathrm{Cu}) 8.902 \mathrm{mgkg}^{-1}(\mathrm{P}<0.01)$ in hyacinth leaves, while calcium $(\mathrm{Ca})$ was $1064.95 \mathrm{mgkg}^{-1}$ and magnesium $(\mathrm{Mg})$ was found $1992.92 \mathrm{mgkg}^{-1}$, and the difference between the mean values for these two elements was not statistically significant. The highest $\mathrm{N}, \mathrm{P}, \mathrm{Zn}$ and $\mathrm{Cu}$ contents of the leaf were obtained by using full dose NPK. The highest mean values of nutrient elements in hyacinth bulbs were 4.382\%; P 278.496 $\mathrm{mgkg}^{-1}$; K, 2.203\%; Ca 2322.045 $\mathrm{mgkg}^{-1}$; $\mathrm{Mg} 1884.164 \mathrm{mgkg}^{-1}$; Mn $39.640 \mathrm{mgkg}^{-1}$; Zn was obtained as $40.861 \mathrm{mgkg}^{-1}$ and $\mathrm{Cu} 7.683 \mathrm{mgkg}^{-1}$, whereas Fe was found to have an average value of 140.545 $\mathrm{mgkg}^{-1}$. In the process of bacteria inoculation $\mathrm{K}, \mathrm{Ca}$ and $\mathrm{Mg}$ content of inoculation; $\mathrm{N}, \mathrm{P}, \mathrm{Mn}, \mathrm{Zn}$ and $\mathrm{Cu}$ content of $1 \frac{1}{2}$ NPK fertilization was determined to be effective.
\end{abstract}

Keywords: Bioorganic fertilization; flowering; Hyacinthus orientalis; inorganic fertilization; nutrient element content; PGPB

\section{Introduction}

Excessive use of chemical fertilizers and pesticides causes deterioration in soil health, environmental pollution, formation of pathogen and harmful populations (Bøckman, 1997; Saber, 2001). The use of inorganic fertilizers cannot provide sustainability in agriculture due to the level of its usage that ecosystems cannot tolerate. Due to the chemicals used, there are many toxic and dangerous chemical substances in 
agricultural ecosystems that penetrate into plants, soil, surface and groundwater and foods (Saber, 2001). Hence, alternatives are sought and studies are carried out in this direction.

In order to get rid of the negative effects of chemical fertilizer use in the world, the trend towards organic fertilizers is increasing. Among the organic fertilizers, Plant Growth Promoting Bacterias(PGPB) are the source of microbial fertilizers (Meena and Rai, 2017; Sonkurt and Çı̆̆, 2019).

Root bacteria with beneficial effects were used in 1978 as the term "root bacteria that stimulate plant growth" (Kleopper and Schroth, 1978). When the studies done in the world are analyzed, it is seen that the term PGPR is generally used for these bacteria. Apart from the effects of stimulating plant growth, PGPRs are known to be effective in biological warfare against diseases, especially soil-borne pathogens (Kloepper, 1993; Lucas et al., 2000; Lemanceau et al., 2000; Parmar and Dadarwal, 2000; Söğüt and Çı̆̆, 2019 ). Now in many countries of the world, studies are contucted on the effects of root bacteria, which are used to stimulate plant growth, to increase yield on plants (Chen et al., 1996; Arias, 2000; Luz, 2000; Romerio, 2000; Wall, 2000).

According to Ekinci et al. (2016); germination rate, root development, yield, leaf area, chlorophyll ratio, nitrogen ratio, protein ratio, hydraulic activity, tolerance to thirst, root and stem weight increasing, delay of aging in leaves and resistance to some diseases are realised with PGPR applications. Beside there are a lot of studies on plant development about the effects of hormones and plant nutrients on ornament plants, the number of studies on the effects of plant growth promoting regulator - PGPR applications, which are frequently emphasized and which can be used as bio fertilizers in agriculture, on ornamental plants is not much (Ekinci et al., 2016). The number of researches on the use of PGPR in hyacinth, which is our subject of study, is almost nonexistent.

Hyacinth is a plant used in landscape design and commercially produced as cut flowers. The desired level of the flowers and bulbs development increase the market value of the hyacinth. In this context, this study is important in terms of revealing how bulbs are affected by inorganic fertilizers or biological fertilizers made with bacteria, and changes in nutrients from soil, especially $\mathrm{N}, \mathrm{P}$ and $\mathrm{K}$ intake.

\section{Materials and Methods}

Materials

Hyacinthus orientalis cv. 'Delft Blue' commercial bulbs were used as plant material in the experiment. Bacteria contaminated with bulbs were selected from nitrogen-fixing and phosphate solubilizing species and were obtained as stock from Siirt University, Faculty of Agriculture, and Department of Field Crops. Nitrogenfixing Cellulomonas turbata (TV54A), phosphate dissolving Bacillus-GC Group (TV119E) and nitrogenfixing and phosphate solubilizing Kluyvera cryocrescens (TV113C) bacteria as well as NPK chemical fertilizer were used.

\section{Experimental design}

The experiment was conducted under laboratory conditions with three replications and five replicates per repetition according to the randomized plot design. A total of seven treatments were applied to the plants which were treated with NPK and bacteria, including the control group.

\section{Fertilizer application}

NPK 20:20:20 half and full doses of chemical fertilizer were applied to the pots one week after planting bulbs, and only once in the form of irrigation water. 


\section{Bacterial application}

The bacteria used in the experiment were obtained from Siirt University, Faculty of Agriculture, and Department of Field Crops. Bacterial isolates were isolated from the Van Lake Basin with the TOVAG $108 \mathrm{O} 147$ TÜBİTAK project and their PGPB activity was detected (Erman et al., 2010). These bacteria were diagnosed with the microbial identification system (MIS) and identified as Plant Growth Promoting Bacteria (PGPB) activity under greenhouse and field conditions.

These bacteria were selected as nitrogen-fixing bacteria which have nitrogen-fixing and phosphate solibilizing properties, were applied alone; an application was also made using a combination of the bacteria Cellulomonas turbata (TV54A) and Bacillus-GC Group (TV119E).

Before planting, all the bulbs were rinsed by surface sterilization in tap water and detergent water, respectively. After that, they were left with $5 \%(\mathrm{v} / \mathrm{v})$ sodium hypochlorite for 20 minutes and washed 3 times with distilled water. In the last stage, bacteria were inoculated for 5 hours on surface sterilized bulbs (Clark, 1965). The bulbs were spread on blotting papers and allowed to dry. These dried bulbs were planted in the pots one day later.

\section{Nutrient analysis}

Nitrogen $(\mathrm{N})$, phosphorus $(\mathrm{P})$ potassium $(\mathrm{K})$, calcium $(\mathrm{Ca})$, magnesium $(\mathrm{Mg})$, iron $(\mathrm{Fe})$, manganese $(\mathrm{Mn}), \mathrm{Zinc}(\mathrm{Zn})$ and copper $(\mathrm{Cu})$ nutrient analysis were performed In leaf samples taken during flowering and bulb samples taken after the above layer of the ground is completely dried. The taken leaf and bulb samples were firstly washed in tap water, then rinsed with pure water and then wilted in laboratory conditions. The next steps were taken at the Science and Technology Application Center of Siirt University, using the methods below:

Samples that were analyzed for nitrogen were dried going through various processes in a Binder brand oven for 48 hours at $65^{\circ} \mathrm{C}$ and analyzed in a device called Thermo Scientific Flash 2000 N-Protein Analyzer. $\mathrm{Ca}$ and $\mathrm{K}$ analyzes were made on Jenway brand PFP7 model flame photometer. $\mathrm{Cu}, \mathrm{Fe}, \mathrm{Zn}, \mathrm{Mn}, \mathrm{Mg}$ and $\mathrm{P}$ analyzes were made with Perkin Elmer ICP-OES Optima 2100 DV. ICP-OES device and were evaluated according to 'Kacar and İnal' (2008).

\section{Statistical evaluations}

The analysis of the data was done in the SAS 9.1 statistical package program according to randomized plot design. Duncan multiple comparison test was used for comparing the averages. Tests were performed at $\alpha$ $=0.05$ significance level (Düzgüneş et al., 1987). Descriptive statistics in terms of the traits were given.

\section{Results and Discussion}

The effect of NPK, nitrogen-fixing and phosphate solibilizing bacteria on the content of the leaves and bulbs of hyacinth plant is given in Figures 1-9.

According to the results of the nutrient analysis performed on the leaves of the hyacinth, the differences between applications were statistically $\mathrm{P}<0.001$ in $\mathrm{N}, \mathrm{P}$ and $\mathrm{Mn}$ contents; $\mathrm{K}, \mathrm{Fe}, \mathrm{Zn}$ and $\mathrm{Cu}$ contents were found to be important at the level of $\mathrm{P}<0.01$, while in $\mathrm{Ca}$ and $\mathrm{Mn}$ contents were found to be insignificant. The highest K content (4.53\%) was found by TV119E bacteria application. NPK fertilization, meanwhile, has the highest $\mathrm{N}(3.87 \%), \mathrm{P}\left(334.79 \mathrm{mg} \mathrm{kg}^{-1}\right), \mathrm{Zn}\left(46.52 \mathrm{mg} \mathrm{kg}^{-1}\right)$ and $\mathrm{Cu}\left(8.90 \mathrm{mg} \mathrm{kg}^{-1}\right)$ contents in the leaf. The highest $\mathrm{Mn}\left(26.74 \mathrm{mg} \mathrm{kg}^{-1}\right)$ and $\mathrm{Mg}\left(1992.92 \mathrm{mg} \mathrm{kg}^{-1}\right)$ contents in the leaf were obtained in TV54A + TV119E bacteria and TV113C inoculation, respectively. The highest $\mathrm{Ca}\left(1064.95 \mathrm{mg} \mathrm{kg}^{-1}\right)$ and $\mathrm{Fe}\left(152.45 \mathrm{mg} \mathrm{kg}^{-1}\right)$ contents were determined in control plants where no application was made (Table 1).

The differences between applications on the contents of $\mathrm{N}, \mathrm{Mg}$ and $\mathrm{Mn}$ in hyacinth bulbs were statistically $\mathrm{P}<0.01$; on $\mathrm{P}, \mathrm{Zn}$ and $\mathrm{Zn}$ contents the level is $\mathrm{P}<0.001$; while on $\mathrm{K}$ and $\mathrm{Ca}$ contents it was 
significant with the level of $\mathrm{P}<0.05$, its effect on Fe content was found insignificant. The highest $\mathrm{N}(4.38 \%)$, $\mathrm{Mn}\left(39.64 \mathrm{mg} \mathrm{kg}^{-1}\right), \mathrm{Zn}\left(40.86 \mathrm{mg} \mathrm{kg}^{-1}\right)$ and $\mathrm{Cu}\left(7.68 \mathrm{mg} \mathrm{kg}^{-1}\right)$ contents in hyacinth bulbs was found in $1 / 2 \mathrm{dose}$ NPK fertilization; while $\mathrm{Ca}\left(2322.05 \mathrm{mg} \mathrm{kg}^{-1}\right)$ and $\mathrm{Mg}\left(1884.16 \mathrm{mg} \mathrm{kg}^{-1}\right)$ contents were found in TV54A and $\mathrm{Fe}\left(140.55 \mathrm{mg} \mathrm{kg}^{-1}\right)$ content in TV54A + TV119E bacteria inoculation, the highest content of $\mathrm{K}(2.20 \%)$ was found in TV113C bacterial inoculation (Table 2).

Table 1. Effects of NPK and bacteria applications on nutrient content in hyacinth leaves

\begin{tabular}{|c|c|c|c|c|c|c|c|c|}
\hline $\begin{array}{c}\text { Applications / } \\
\text { Nutrient elements }\end{array}$ & Control & NPK & $1 / 2 \mathrm{NPK}$ & TV54A & TV119E & $\begin{array}{c}\text { TV54A + } \\
\text { TV119E }\end{array}$ & TV113C & $\begin{array}{c}\text { Significant } \\
\text { degree }\end{array}$ \\
\hline $\mathrm{N}(\%)^{* * *}$ & $3.23 \mathrm{CD}$ & $3.87 \mathrm{~A}$ & $3.44 \mathrm{~B}$ & $3.32 \mathrm{BC}$ & $3.11 \mathrm{D}$ & $3.12 \mathrm{D}$ & $3.10 \mathrm{D}$ & $\mathrm{P}<0.001$ \\
\hline $\mathrm{P}\left(\mathrm{mg} \mathrm{kg}^{-1}\right)^{* * *}$ & $319.52 \mathrm{~A}$ & 334.79 & $286.82 \mathrm{AB}$ & $129.70 \mathrm{C}$ & $116.37 \mathrm{C}$ & $78.75 \mathrm{C}$ & $167.19 \mathrm{BC}$ & $\mathrm{P}<0.001$ \\
\hline $\mathrm{K}^{* *}(\%)$ & $\begin{array}{c}3.72 \\
\mathrm{C}\end{array}$ & $\begin{array}{c}3.86 \\
\mathrm{BC}\end{array}$ & $\begin{array}{c}3.91 \\
\mathrm{BC}\end{array}$ & $\begin{array}{c}3.95 \\
\mathrm{ABC}\end{array}$ & $\begin{array}{c}4.53 \\
\mathrm{~A}\end{array}$ & $\begin{array}{c}4.44 \\
\mathrm{AB}\end{array}$ & $\begin{array}{c}4.30 \\
\text { ABC }\end{array}$ & $\mathrm{P}<0.01$ \\
\hline $\mathrm{Ca}\left(\mathrm{mg} \mathrm{kg}^{-1}\right)$ & 1064.95 & 897.50 & 918.80 & 958.68 & 814.21 & 570.00 & 539.70 & $\mathrm{NS}$ \\
\hline $\mathrm{Mg}\left(\mathrm{mg} \mathrm{kg}^{-1}\right)$ & 1694.72 & 1907.58 & 1826.22 & 1851.96 & 1816.91 & 1958.47 & 1992.92 & $\mathrm{NS}$ \\
\hline $\mathrm{Fe}\left(\mathrm{mg} \mathrm{kg}^{-1}\right)^{* *}$ & $\begin{array}{c}152.45 \\
\mathrm{~A}\end{array}$ & $\begin{array}{c}123.83 \\
\mathrm{ABC}\end{array}$ & $\begin{array}{c}94.13 \\
\mathrm{BC}\end{array}$ & $\begin{array}{c}132.93 \\
\mathrm{AB}\end{array}$ & $\begin{array}{c}89.89 \\
\mathrm{C}\end{array}$ & $\begin{array}{c}117.82 \\
\mathrm{ABC}\end{array}$ & $\begin{array}{c}120.96 \\
\text { ABC }\end{array}$ & $\mathrm{P}<0.01$ \\
\hline $\mathrm{Mn}\left(\mathrm{mg} \mathrm{kg}^{-1}\right)^{* * *}$ & $20.47 \mathrm{~B}$ & $25.36 \mathrm{~A}$ & $20.32 \mathrm{~B}$ & $25.88 \mathrm{~A}$ & $26.03 \mathrm{~A}$ & $26.74 \mathrm{~A}$ & $24.53 \mathrm{~A}$ & $\mathrm{P}<0.001$ \\
\hline $\mathrm{Zn}\left(\mathrm{mg} \mathrm{kg}^{-1}\right)^{* *}$ & $44.32 \mathrm{AB}$ & $46.52 \mathrm{~A}$ & $43.95 \mathrm{AB}$ & $39.42 \mathrm{BC}$ & $37.76 \mathrm{C}$ & $42.55 \mathrm{ABC}$ & $39.86 \mathrm{BC}$ & $\mathrm{P}<0.01$ \\
\hline $\mathrm{Cu}\left(\mathrm{mg} \mathrm{kg}^{-1}\right)^{* *}$ & $8.04 \mathrm{AB}$ & $8.90 \mathrm{~A}$ & $8.04 \mathrm{AB}$ & $6.72 \mathrm{BC}$ & $6.38 \mathrm{C}$ & $6.38 \mathrm{C}$ & $6.94 \mathrm{BC}$ & $\mathrm{P}<0.01$ \\
\hline
\end{tabular}

NS: Not significant, ${ }^{* *}: \mathrm{p}<0.01^{* * *}: \mathrm{p}<0.001$; Means followed by the same letter indicate no statistical difference

TV54A: Nitrogen-fixing bacteria-Cellulomonas turbata; TV119E: Phosphate solubilizing bacteria-Bacillus-GC

Group; TV113C: Nitrogen-fixing and phosphate solibilizing bacteria -Kluyvera cryocrescens

Table 2. Effects of NPK and bacteria applications on nutrient content in hyacinth bulbs

\begin{tabular}{|c|c|c|c|c|c|c|c|c|}
\hline $\begin{array}{c}\text { Applications / } \\
\text { Nutrient elements }\end{array}$ & Control & NPK & $1 / 2 \mathrm{NPK}$ & TV54A & TV119E & $\begin{array}{c}\text { TV54A } \\
+ \\
\text { TV119E }\end{array}$ & TV113C & $\begin{array}{l}\text { Significant } \\
\text { degree }\end{array}$ \\
\hline $\mathrm{N}(\%)^{* *}$ & $2.48 \mathrm{~B}$ & $3.67 \mathrm{AB}$ & $4.38 \mathrm{~A}$ & $3.34 \mathrm{AB}$ & $2.23 \mathrm{~B}$ & $2.89 \mathrm{AB}$ & $2.94 \mathrm{AB}$ & $\mathrm{P}<0.01$ \\
\hline $\mathrm{P}\left(\mathrm{mg} \mathrm{kg}^{-1}\right)^{* * *}$ & $278.50 \mathrm{~A}$ & $214.74 \mathrm{~A}$ & $250.28 \mathrm{~A}$ & $60.06 \mathrm{~B}$ & $93.04 \mathrm{~B}$ & $21.09 \mathrm{~B}$ & $65.88 \mathrm{~B}$ & $\mathrm{P}<0.001$ \\
\hline $\mathrm{K}(\%)^{*}$ & $1.67 \mathrm{~B}$ & $1.97 \mathrm{AB}$ & $2.03 \mathrm{AB}$ & $1.93 \mathrm{AB}$ & $1.81 \mathrm{AB}$ & $1.86 \mathrm{AB}$ & $2.20 \mathrm{~A}$ & $\mathrm{P}<0.05$ \\
\hline $\mathrm{Ca}\left(\mathrm{mg} \mathrm{kg}^{-1}\right)^{*}$ & $\begin{array}{c}733.83 \\
\text { B } \\
\end{array}$ & $\begin{array}{c}1184.32 \\
\mathrm{AB}\end{array}$ & $\begin{array}{c}1095.71 \\
\mathrm{AB}\end{array}$ & $\begin{array}{c}2322.05 \\
\mathrm{~A}\end{array}$ & $\begin{array}{c}1509.86 \\
\mathrm{AB}\end{array}$ & $\begin{array}{c}1111.40 \\
\mathrm{~B}\end{array}$ & $\begin{array}{c}1156.10 \\
\mathrm{AB}\end{array}$ & $\mathrm{P}<0.05$ \\
\hline $\mathrm{Mg}\left(\mathrm{mg} \mathrm{kg}^{-1}\right)^{* *}$ & $\begin{array}{c}964.53 \\
\text { B }\end{array}$ & $\begin{array}{c}1414.43 \\
\text { AB }\end{array}$ & $\begin{array}{c}1588.82 \\
\text { A }\end{array}$ & $\begin{array}{c}1884.16 \\
\text { A }\end{array}$ & $\begin{array}{c}1620.99 \\
\text { A }\end{array}$ & $\begin{array}{c}1521.09 \\
\text { A }\end{array}$ & $\begin{array}{c}1627.49 \\
\text { A }\end{array}$ & $\mathrm{P}<0.01$ \\
\hline $\mathrm{Fe}\left(\mathrm{mg} \mathrm{kg}^{-1}\right)$ & 71.89 & 80.26 & 91.15 & 103.29 & 91.43 & 140.55 & 95.59 & NS \\
\hline $\operatorname{Mn}\left(\mathrm{mg} \mathrm{kg}^{-1}\right)^{* *}$ & $\begin{array}{c}22.15 \\
\mathrm{C}\end{array}$ & $\begin{array}{l}30.32 \\
\mathrm{ABC}\end{array}$ & $\begin{array}{c}39.64 \\
\text { A }\end{array}$ & $\begin{array}{c}36.45 \\
\mathrm{AB}\end{array}$ & $\begin{array}{c}27.44 \\
\text { BC }\end{array}$ & $\begin{array}{c}29.67 \\
\text { BC }\end{array}$ & $\begin{array}{c}33.55 \\
\mathrm{AB}\end{array}$ & $\mathrm{P}<0.01$ \\
\hline $\mathrm{Zn}\left(\mathrm{mg} \mathrm{kg}^{-1}\right)^{* * *}$ & $32.43 \mathrm{BC}$ & $35.88 \mathrm{AB}$ & $40.86 \mathrm{~A}$ & $24.24 \mathrm{D}$ & $21.71 \mathrm{D}$ & $21.77 \mathrm{D}$ & $26.51 \mathrm{CD}$ & $\mathrm{P}<0.001$ \\
\hline $\mathrm{Cu}\left(\mathrm{mg} \mathrm{kg}^{-1}\right)^{* * *}$ & $6.42 \mathrm{AB}$ & $6.54 \mathrm{AB}$ & $7.68 \mathrm{~A}$ & $4.56 \mathrm{C}$ & $4.72 \mathrm{C}$ & $4.38 \mathrm{C}$ & $5.28 \mathrm{BC}$ & $\mathrm{P}<0.001$ \\
\hline
\end{tabular}

NS: Not significant, ${ }^{*}: \mathrm{p}<0.05,{ }^{* *}: \mathrm{p}<0.01,{ }^{* * *}: \mathrm{p}<0.001$; Means followed by the same letter indicate no statistical difference

TV54A: Nitrogen-fixing bacteria-Cellulomonas turbata; TV119E: Phosphate solibilizing bacteria-Bacillus-GC

Group; TV113C: Nitrogen-fixing and phosphate solibilizing bacteria -Kluyvera cryocrescens 


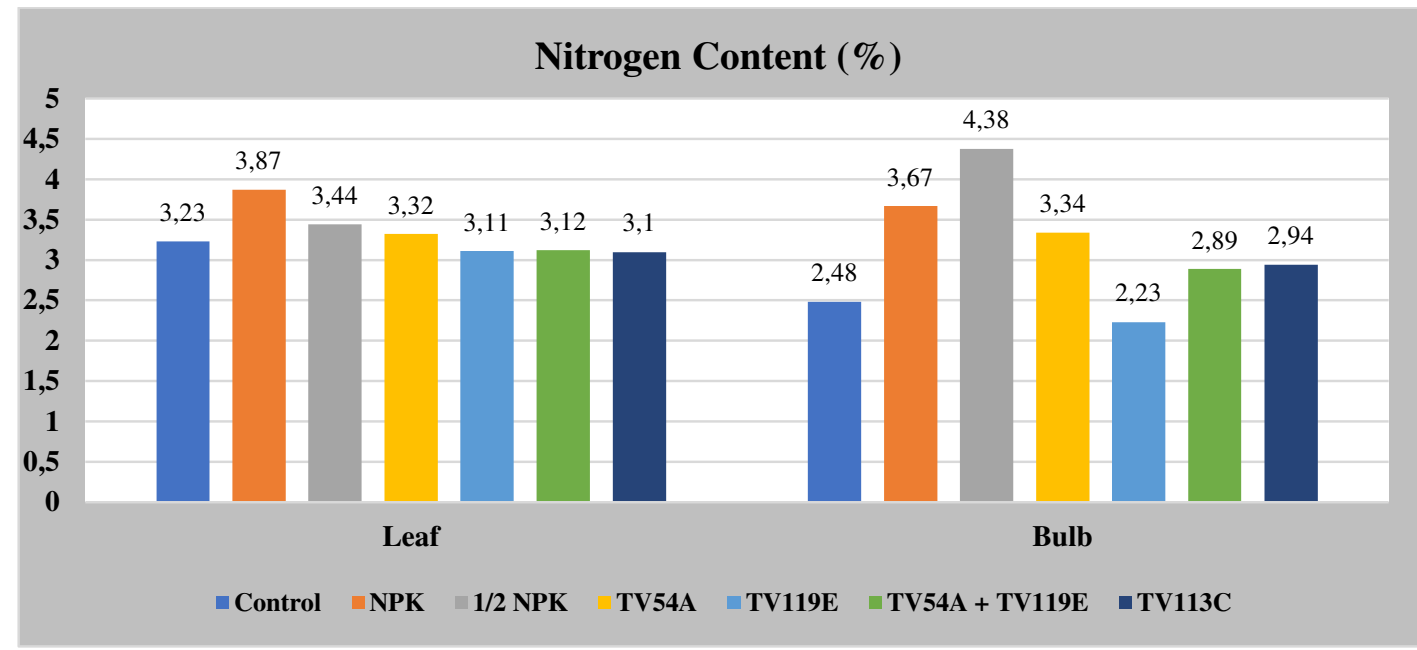

Figure 1. Nitrogen content of leaves and bulbs of hyacinth

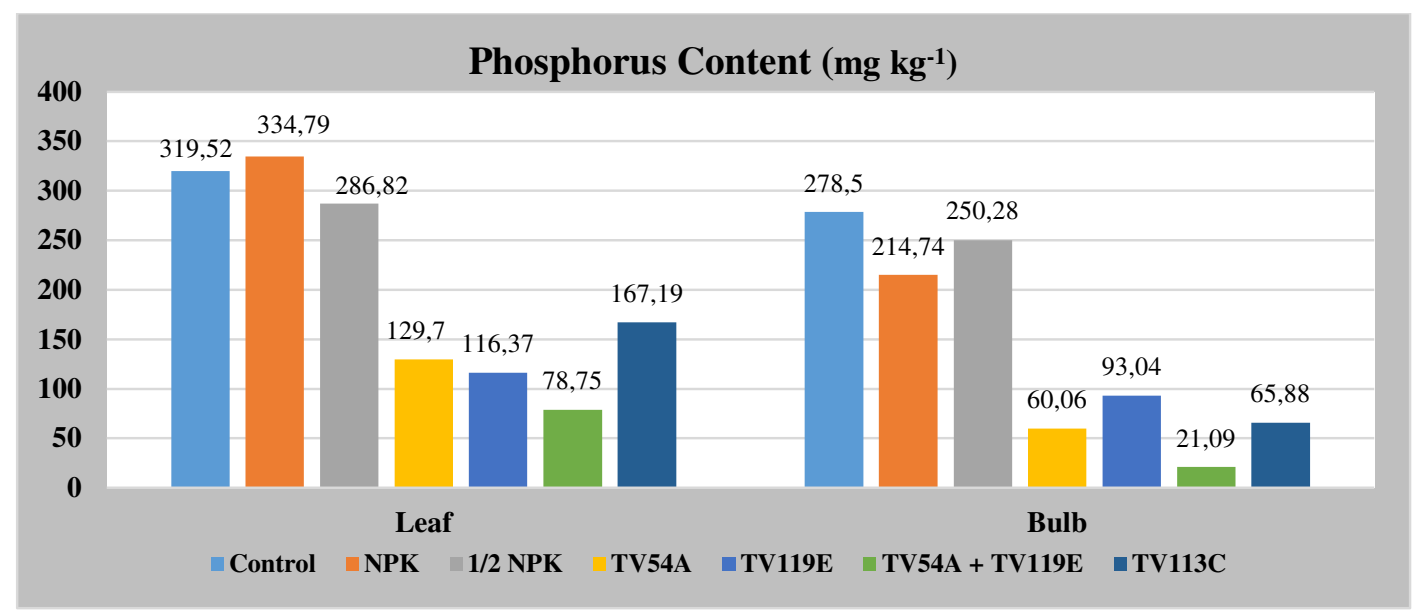

Figure 2. Phosphorus content of leaves and bulbs of hyacinth

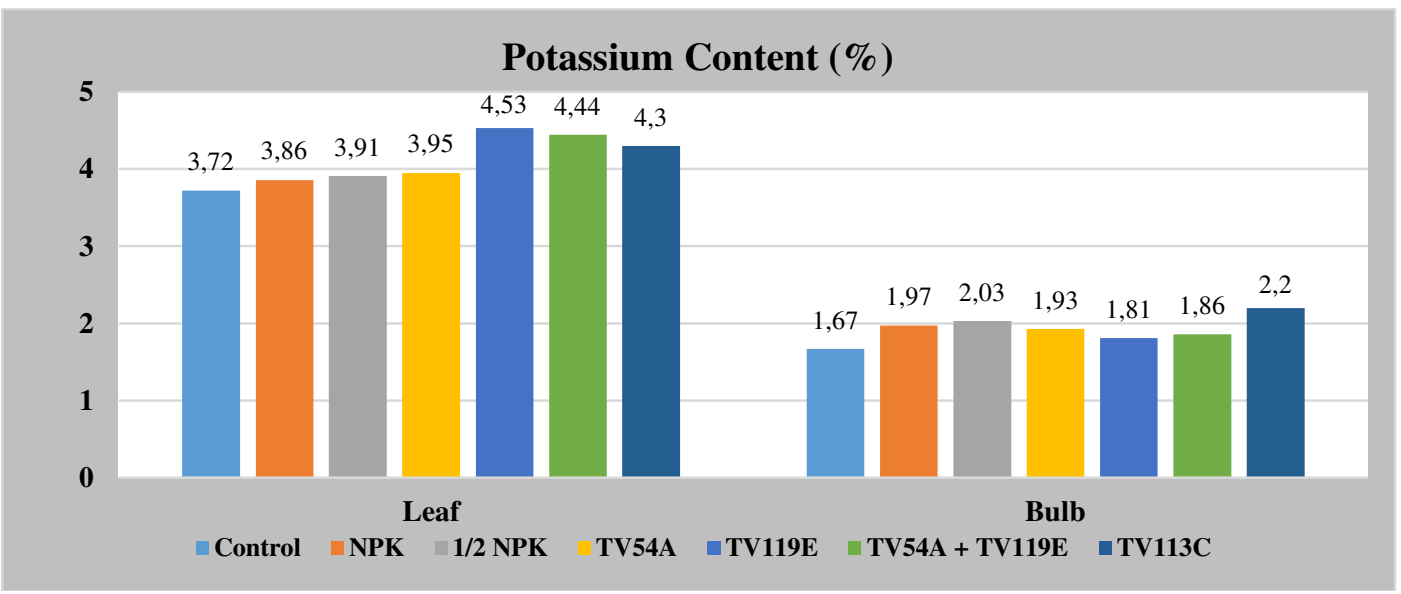

Figure 3. Potassium content of leaves and bulbs of hyacinth 


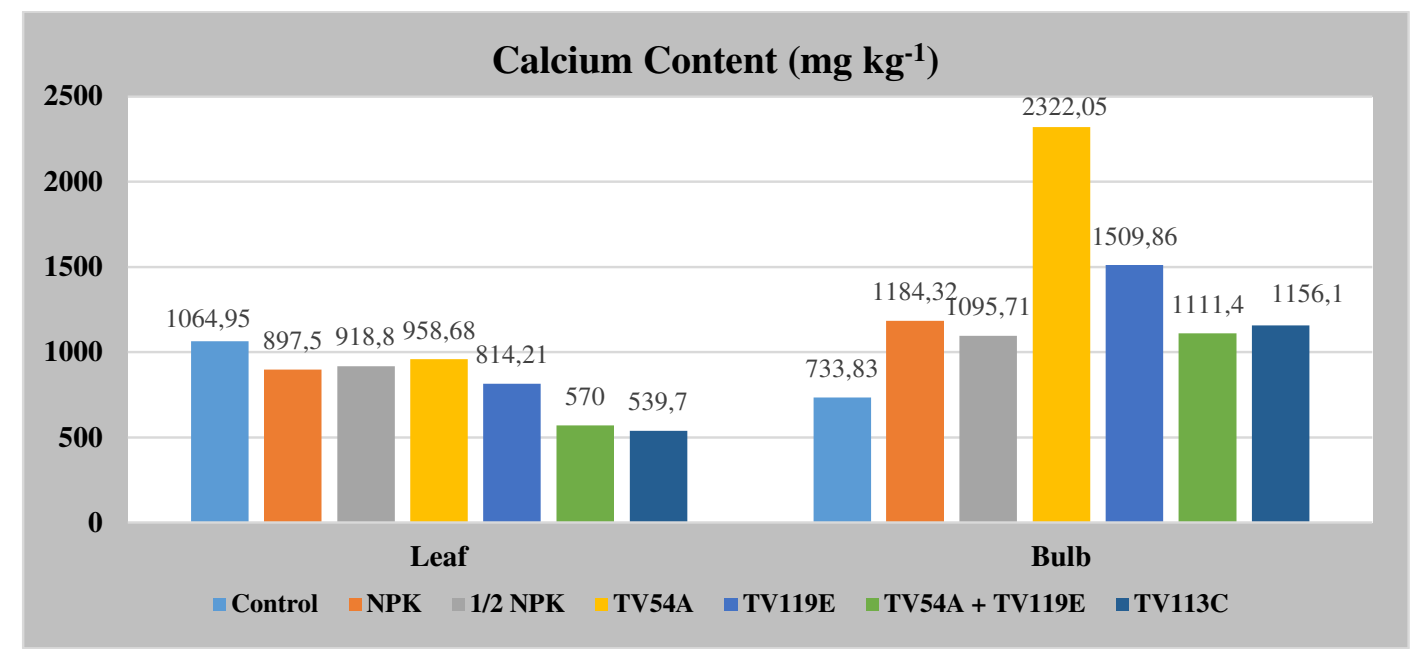

Figure 4. Calcium content of leaves and bulbs of hyacinth

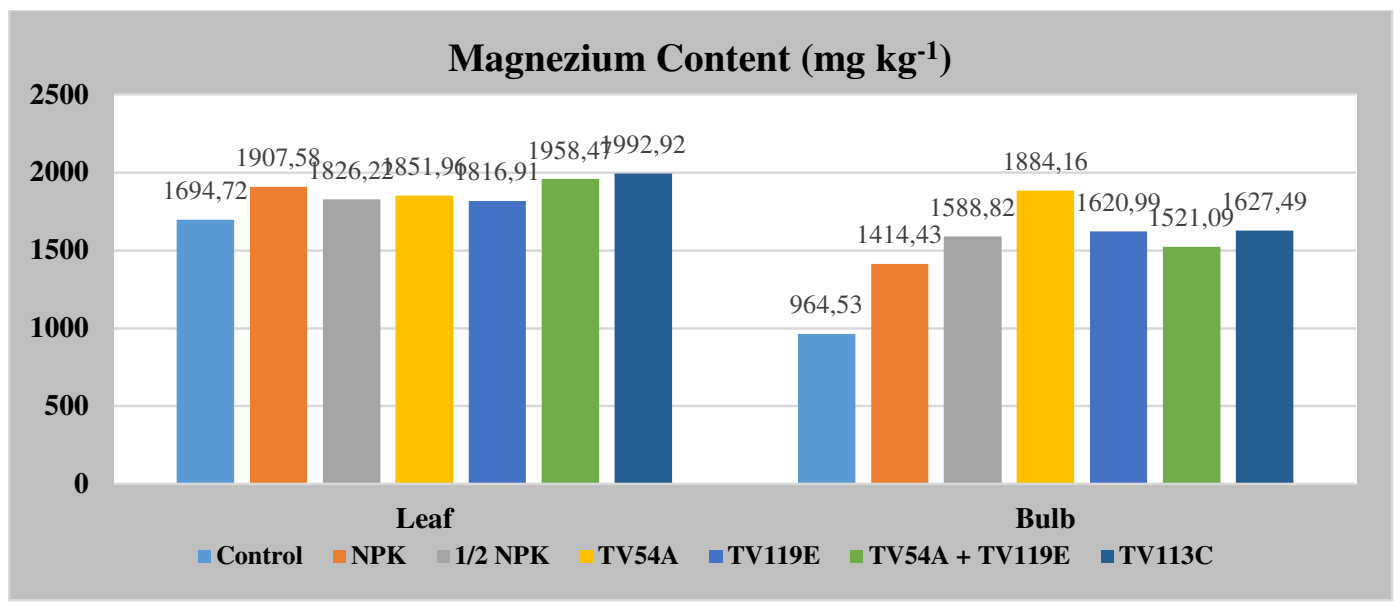

Figure 5. Magnezium content of leaves and bulbs of hyacinth

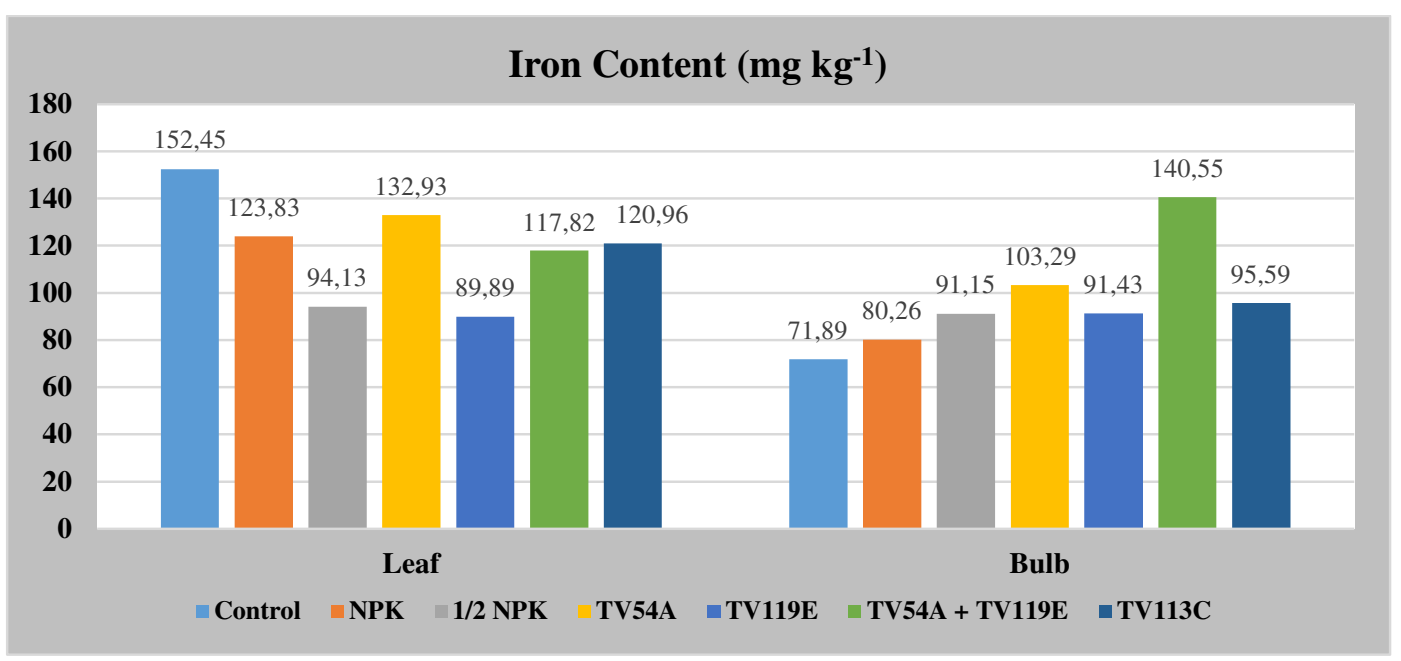

Figure 6. Iron content of leaves and bulbs of hyacinth 


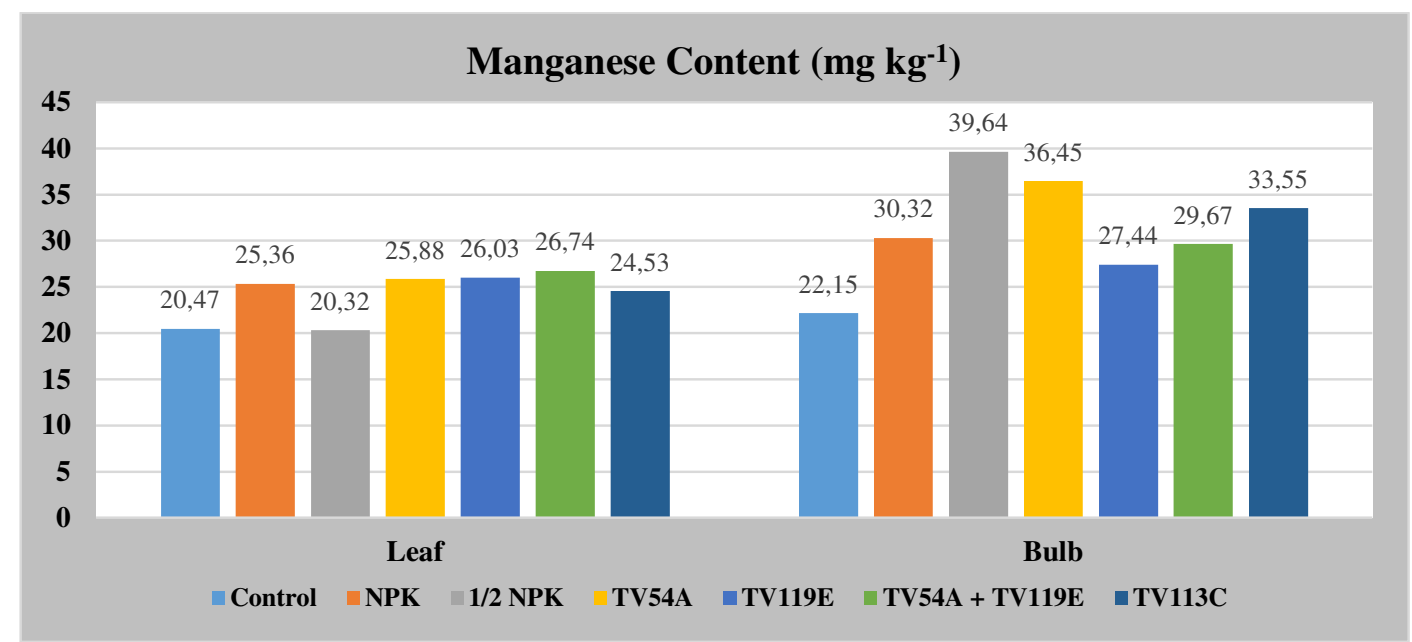

Figure 7. Manganese content of leaves and bulbs of hyacinth

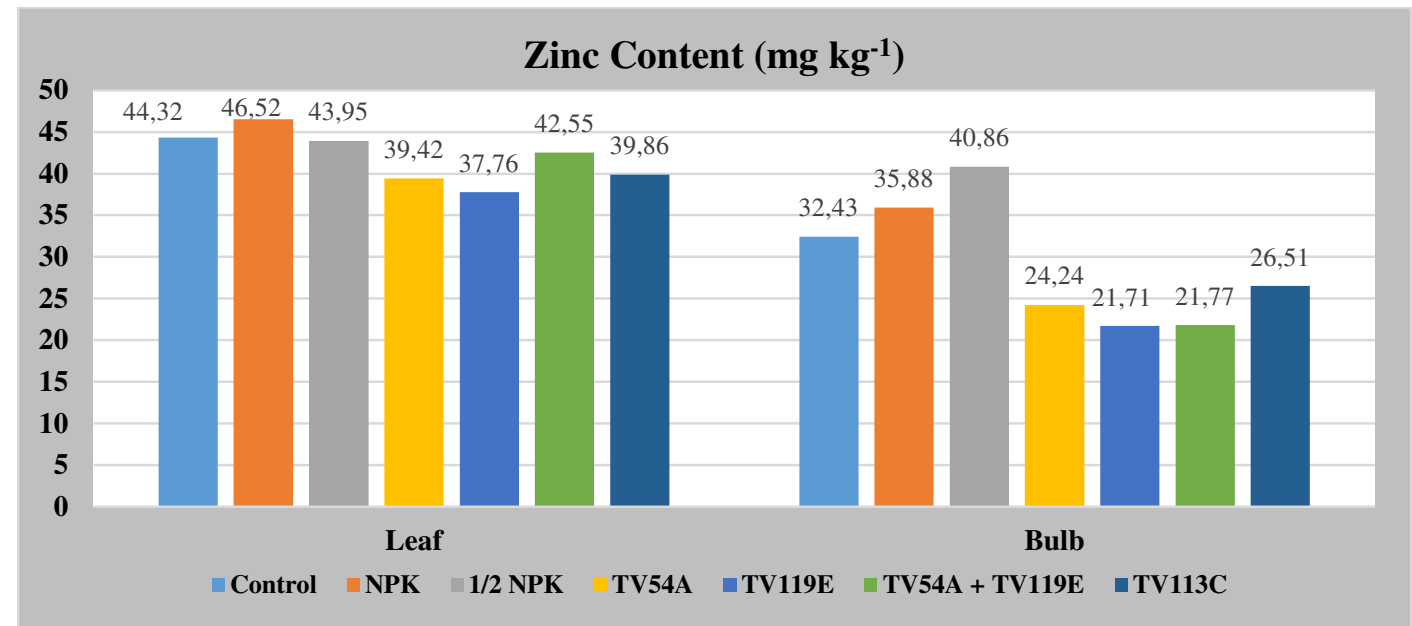

Figure 8. Zinc content of leaves and bulbs of hyacinth

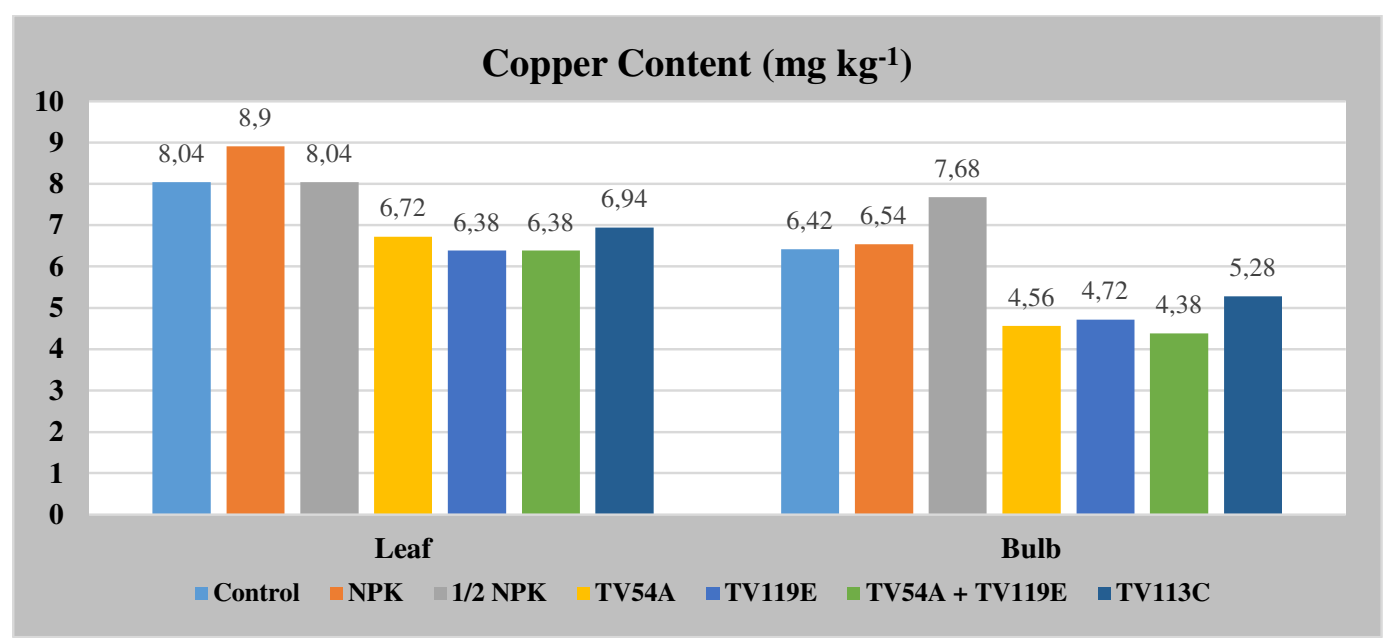

Figure 9. Copper content of leaves and bulbs of hyacinth 
The lowest $\mathrm{N}$ content was obtained in bacterial applications and in the control group leaves and bulbs; whereas, NPK and $1 / 2$ NPK fertilizers were found to have a positive effect on nitrogen content. It is understood that the phosphorus content in leaves and bulbs is also obtained more in control and fertilizer applications, similar to nitrogen content, than in bacterial inoculum. Bacterial inoculation did not have a positive effect on the phosphorus content in the hyacinth plant. The lowest level of $\mathrm{K}$ content is found in the control plants' leaves and bulbs, it was, meantime, found to be higher especially in the leaves of all bacterial inoculated plants than those with NPK fertilization. K content in bulbs was obtained close to each other as a result of bacteria and fertilization applications. Ca content has the highest average in the control group of leaves, however received the lowest value in bulbs. Ca average values in bulbs were statistically in the same group in all other applications except with highest level in TV54A inoculation. Although the difference between the Ca values in the leaves is statistically insignificant, the difference between the highest and the lowest values appears to be distinct. $\mathrm{Mg}$ content in leaves and bulbs was lower in control plants than in other applications. The positive effect of bacteria on $\mathrm{Mg}$ content can be mentioned in both part of the plants. The lowest Fe content in bulb was obtained from control plants, while TV119E bacterial inoculation application, where the lowest Fe content is obtained in the leaf, causes an increase in Fe content in bulbs. Mn content had low mean values in the control plants'leaves and bulbs. Other applications caused an increase. $\mathrm{Zn}$ and $\mathrm{Cu}$ contents were determined to be lower in bacterial inoculation in both leaf and bulb than in control and fertilizer applications. $\mathrm{Zn}$ and $\mathrm{Cu}$ contents decreased with bacterial inoculation.

NPK and PGPR applications considerably affected hyacinth bulbs' concentrations of macro and micro plant nutrient content. N, P, Ca, Fe, $\mathrm{Zn}$ and $\mathrm{Cu}$ contents decrease in hyacinth leaf with bacterial applications, while increase in $\mathrm{K}, \mathrm{Mg}$ and $\mathrm{Mn}$ contents were observed. Again, with bacterial applications in hyacinth bulbs, while the N, P, Mn, $\mathrm{Zn}$ and $\mathrm{Cu}$ content decreases, increases in $\mathrm{K}, \mathrm{Ca}, \mathrm{Mg}$ and $\mathrm{Fe}$ contents were determined.

With the help of bacterial applications, boost in nutrient uptake, implementing plant growth hormones, raising chlorophyll content and organic acids, it is fairly possible to increase the plant growth. (Parlakova Karagöz et al., 2019). Previous studies are coherent with the present ones in this matter. (Shen et al., 2004; Zare et al., 2011; Parewa et al., 2014; Parlakova Karagöz et al., 2016). PGPR applications have reported the highest $\mathrm{K}, \mathrm{Mg}$ and Mn contents. These bacteria applications are, respectively, the TV119E, TV113C and TV54A + TV119E.

The highest bulb nutrient contents with bacterial applications were obtained in $\mathrm{Ca}, \mathrm{K}, \mathrm{Mg}$ and $\mathrm{Fe}$, in TV54A, TV113C, TV54A and TV54A + TV119E applications, respectively.

Pseudomonas+Azotobacter application had significantly diverged from other similar PGPR applications with the the highest P, K, Mg Ca contents (Zare et al., 2011). Alongside, Pseudomonas putida application revealed the highest $\mathrm{Mg}, \mathrm{Fe}, \mathrm{Mn}$ and Zn contents. (Parlakova Karagöz et al., 2019). Bashir et al. (2019) found that they improved the supply of the element $\mathrm{K}$ in their field study with tulip (Tulipa gesneriana L. cv. 'Clear Water'). In another study conducted with gilliflower, it was reported that there was an increase in K content similar to this study with the application of microbial fertilizer (Eid et al., 2009).

It is possible that PGPR inoculation is able to counterpoise for nutrient deficiency, also plant's rootzone microorganisms can improve a plant development. It can quicken root development of plants, and as a denouement the better absorption of nutrients and water from the grown medium will be possible (Egamberdiyeva, 2007; Soussi et al., 2016).

Unlike the other studies (Eid et al., 2009; Parlakova Karagöz et al., 2019), compared to NPK and control applications, lower values of microbial fertilizer applications in $\mathrm{N}$ and $\mathrm{P}$ intake of hyacinth leaves and bulbs were obtained. According to Çı̆ and Çı̆ (2019), the control plants demonstrated the highest value (with no bacterial application and fertilization) of the weight, length and width of hyacinth bulb (both laboratuary and field conditions), however bacterial applications had negative effects on these values. In connection with the effect of researchers have set on the development of bulbs, both the nutrient content and bulbs and leaves are in similar parallel with our study. 


\section{Conclusions}

In the construed literatures, it has been observed that bacteria generally increase the growth and nutrition rate in the plant. Nevertheless, in our study, it was revealed that inorganic fertilization is more stimulating than bacterial inoculation. This situation, which is thought to be due to the dose of NPK used, may change with perhaps less dose usage. On the other hand, the nutrient content of plants that underwent bacterial inoculation in leaf and bulb nutrition, was below the control group values for some elements. In this study of hyacinth plant used as an ornament plant, bacterial inoculations were found to have less effect in terms of flowering and nutrient content than the commercial fertilizer N: P: K used at 20:20:20 rate. By conducting similar studies, the effect of inoculation of different bacteria, which are still useful, can be determined on the flower criteria. The idea that comparison of the effects of inorganic and bio-organic fertilizers will be possible by also reducing the inorganic fertilizer dose a little more emerges. As in previous studies, bacterial application together with inorganic fertilizer may increase the growth and flowering performance of the plant. With the belief that the use of bio-organic fertilizers should achieve the threshold of reaching the effect of commercial fertilizers, the idea that biological fertilizer should be an alternative fertilization route for hyacinths and other ornament plants should be adopted with regard to the pollution and cost of the inorganic fertilizers, that are used more than its needed.

It has been reported that the effect levels of the bacteria will differ according to the bacterial strain, application type, temperature, soil type and plant type (Egamberdiyeva and Höflich, 2003). According to the researchers who have made similar discourses, bacterial effects that stimulate plant growth can vary depending on the type of bacteria, the number of plant - bacteria combinations, the plant genotype, the growth period, the harvest date, the plant parameters, soil type, the amount of organic substance and environmental conditions (Şahin et al., 2004; Çakmakçı et al., 2006). This information is very significant in terms of evaluating the results of our research. In our study of hyacinth plant, which is a perennial type of geophyte, bacteria are transmitted to flower bulbs. The idea that bacterial application can be considered from leaf, withal the possibility of changing the growing conditions (temperature and soil type) come to mind.

\section{Authors' Contributions}

Conceptualization: AÇ; Data curation: AÇ; Investigation: PAB; Methodology: AÇ; Project administration: AÇ; Resources PAB; Software: Supervision: NT; Validation: NT; Visualization PAB; Writing - original draft: PAB; Writing - review and editing: AÇ. All authors read and approved the final manuscript.

\section{Acknowledgements}

This work was supported by the Siirt University Coordinator of Scientific Research and Projects, grant number 2017-SİÜFEB-88. This study was produced from the master's thesis of the author P.A.B.

\section{Conflict of Interests}

The authors declare that there are no conflicts of interest related to this article. 


\section{References}

Arias A (2000). Plant growth promoting microorganisms in Uruguay: status and prospects, In: Proceedings of the Fifth International PGPR Workshop, Cordoba, Argentina.

Bashir M, Asif M, Naveed M, Qadri RWK, Faried N, Baksh A (2019). Pre-harvest exogenous application of bacterial strains to assess the flower and bulb quality of cut tulip (Tulipa gesneriana L.) cv. 'Clear Water'. Discovery 55(278):73-80.

Bøckman OC (1997). Fertilizers and biological nitrogen fixation as sources of plant nutrients: perspectives for future agriculture. Plant Soil 194:11-14.

Chen Y, Mei R, Lu S, Liu L, Kloepper JW (1996). The use of yield increasing bacteria (yib) as plant growth promoting rhizobacteria in Chinese agriculture. Management of soil borne diseases. Utkhede RS, Gupta VK (Eds). Kalyani Publishers, Ludhiada, New Delhi, pp 165-184.

Clark DS (1965). Method for estimating the bacterial population on surfaces. Canadian Journal of Microbiology 11(3):407-413. https://doi.org/10.1139/m65-054

Çakmakçi R, Dönmez F, Aydın A, Şahin F (2006). Growth promotion of plants by plant growth-promoting rhizobacteria under greenhouse and two different field soil conditions. Soil Biology Biochemistry 38(6):1482-1487. https://doi.org/10.1016/j.soilbio.2005.09.019

Çı̆̆ A, Çı̆̆ F (2019). The effect of some PGPBs on post-harvest weight, length and width of Hyacinth bulbs planted in different areas. In: Proceedings of the 2nd International Conference on Food, Agriculture and Animal Sciences (ICOFAAS 2019) Antalya, Turkey pp 258-268.

Düzgünes O, Kesici T, Kavuncu O, Gürbüz F (1987). Araştırma ve deneme metotları, Yayın No: 1021, Ders Kitabı: 295, A.Ü.Ziraat Fakültesi Yayınları, Ankara, 381. (in Turkish)

Egamberdiyeva D (2007). The effect of plant growth promoting bacteria on growth and nutrient uptake of maize in two different soils. Applied Soil Ecology 36(23):184-189. https://doi.org/10.1016/j.apsoil.2007.02.005

Egamberdiyeva D, Höflich G (2003). Influence of growth promoting bacteria on the growth of wheat in different soils and temperatures. Soil Biology \& Biochemistry 35:973-978. https://doi.org/10.1016/S0038-0717(03)00158-5

Eid AR, Awad MN, Hamouda HA (2009). Evaluate effectiveness of bio and mineral fertilization on the growth parameters and marketable cut flowers of Matthiola incana L. American-Eurasian Journal of Agriculture and Environmental Science 5(4):509-518.

Ekinci M, Dursun A, Kotan R, Güneş A (2016). Azot fikseri ve fosfat çözücü bakteri izolatlarının farklı lale çeşitlerinde oluşan soğan sayısı ve bazı bitkisel özellikleri üzerine etkilerinin incelenmesi, TÜBİTAK Proje Sonuç Raporu. Program Kodu: 1001. Proje No: 1130957. (in Turkish)

Erman M, Kotan R, Çakmakçı R, Çı̆̆ F, Karagöz K, Sezen M (2010). Effect of nitrogen fixing and phosphatesolubilizing rhizobacteria isolated from Van Lake Basin on the growth and quality properties in wheat and sugar beet. In: Proceedings of the Turkey IV. Organic Farming Symposium, Erzurum, Turkey, pp 325-329.

Kacar B, İnal A (2008). Bitki analizleri. Nobel Yayın, No: 1241, Fen Bilimleri: 63. (in Turkish)

Kleopper JW, Schroth MN (1978). Plant growth promoting rhizobacteria on radishes. In: Proceedings of the Fourth International Conference on Plant Pathogenic Bacteria 2:879-882.

Kloepper JW (1993). Plant growth promoting rhizobacteria as biological control agents. Soil Microbial Ecology. F Blaşne Metting J (Ed.) Marcel Dekker, Inc. New York pp 255-274.

Lemanceau P, Steinberg C, Thomas DJI, Edel V, Raaijmakers J, Alabouvette C (2000). Natural soil suppressiveness to soilborne diseases. In: Proceedings of the Fifth International PGPR Workshop, Cordoba, Argentina.

Lucas Garcia JA, Probanza A, Ramos B, Ruiz Palomino N, Gutierrez Manero FJ (2000). Effects of inoculation with PGPR on seedling growth of different tomato and pepper varieties in axenic conditions. In: Proceedings of the Fifth International PGPR Workshop, Cordoba, Argentina.

Luz WC (2000). Plant growth promoting rhizobacteria in graminicolous crops in Brazil. In: Proceedings of the Fifth International PGPR Workshop, Cordoba, Argentina.

Meena P, Rai A (2017). Effect of PGPR on morphological properties of different varieties of wheat (Triticum aestivum). The Pharma Innovation 6(7):271-277. https://doi.org/10.4236/aim.2016.69067

Parewa HP, Yadav J, Rakshit A, Meena VS, Karthikeyan N (2014). Plant growth promoting rhizobacteria enhance growth and nutrient uptake of crops. Agriculture for Sustainable Development 2(2):101-116. 
Parlakova Karagöz F, Dursun A, Kotan R (2019). Effects of rhizobacteria on plant development, quality of flowering and bulb mineral contents in Hyacinthus orientalis L. Alinteri Journal of Agriculture Sciences 34(1):88-95. bttps://doi.org/10.28955/alinterizbd.585219

Parlakova Karagöz F, Dursun A, Kotan R, Ekinci M, Yildirim E, Mohammadi P (2016). Assessment of the effects of some bacterial isolates and hormones on corm formation and some plant properties in saffron (Crocus sativus L.). Ankara University Journal of Agricultural Sciences 22(4):500-511.

Parmar N, Dadarwal KR (2000). Pathogenic suppressive abilities of rhizosphere bacteria from healthy chickpea plants. In: Proceedings of the Fifth International PGPR Workshop, Cordoba, Argentina.

Romerio RS (2000). Preliminary results on PGPR research at the Universidade Federal De Viçosa, Brazil. In: Proceedings of the Fifth International PGPR Workshop, Cordoba, Argentina.

Saber MSM (2001). Clean biotechnology for sustainable farming. Engineering Life Sciences 1:217-223. https://doi.org/10.1002/1618-2863(200112)1:6<217::AID-ELSC217>3.0.CO;2-Y

Shen J, Li R, Zhang F, Fan J, Tang C, Rengel Z (2004). Crop yields, soil fertility and phosphorus fractions in response to long-term fertilization under rice monoculture system on a calcareous soil. Field Crops Research 86:225-238. https://doi.org/10.1016/j.fcr.2003.08.013

Sonkurt M, Çı̆̆ F (2019). The effect of plant growth-promoting bacteria on the development, yield and yield components of bread (Triticum aestivum L.) and durum (Triticum durum) wheats. Applied Ecology and Environmental Research 17(2):3877-3896. http://dx.doi.org/10.15666/aeer/1702_38773896

Soussi A, Ferjani R, Marasco R, Guesmi A, Cherif H, Rolli E, ... Cherif A (2016). Plant-associated microbiomes in arid lands: Diversity, ecology and biotechnological potential. Plant and Soil 405(1-2):357-370. https://doi.org/10.1007/s11104-015-2650-y

Sögüt S, Çı̆̆ F (2019). Determination of the effect of plant growth promoting bacteria on wheat (Triticum aestivum $\mathrm{L}$.) development under salinity stress conditions. Applied Ecology and Environmental Research 17(1):1129-1141. https://doi.org/10.15666/aeer/1701_11291141

Şahin F, Çakmakçi R, Kantar F (2004). Sugar beet and barley yields in relation to inoculation with $\mathrm{N}_{2}$-fixing and phosphate solubilizing bacteria. Plant and Soil 265:123-129. https://doi.org/10.1007/s1 1104-005-0334-8

Wall LG (2000). Consequences of an overview on PGPR work in Argentina: The field should be wider. In: Proceedings of the Fifth International PGPR Workshop, Cordoba, Argentina.

Zare M, Ordookhani K, Alizadeh O (2011). Effects of PGPR and AMF on growth of two bred cultivars of tomato. Advances in Environmental Biology 5(8):2177-2181.
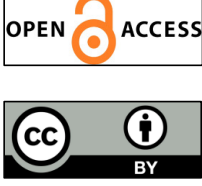

The journal offers free, immediate, and unrestricted access to peer-reviewed research and scholarly work. Users are allowed to read, download, copy, distribute, print, search, or link to the full texts of the articles, or use them for any other lawful purpose, without asking prior permission from the publisher or the author.

License - Articles published in Notulae Botanicae Horti Agrobotanici Cluj-Napoca are Open-Access, distributed under the terms and conditions of the Creative Commons Attribution (CC BY 4.0) License.

(c) Articles by the authors; UASVM, Cluj-Napoca, Romania. The journal allows the author(s) to hold the copyright/to retain publishing rights without restriction. 